\title{
Risk Estimation of Aortic Stiffness in Patients with End Stage Renal Disease under Maintenance Haemodialysis
}

\author{
MD RASUL AMIN ${ }^{1}$, ABDUR RAZZAK ${ }^{2}$, GM SADIK HASAN ${ }^{3}$, A.N.M. ABDUL HAI ${ }^{3}$, CHAYAN KUMAR SINGHO ${ }^{1}$, \\ SM EAR-E-MAHBUB ${ }^{1}$, MD FAISAL IBN KABIR ${ }^{1}$, MUSTASHIRUL HAQUE ${ }^{1}$, ELORA SHARMIN ${ }^{1}$ \\ ${ }^{1}$ Bangabandhu Sheikh Mujib Medical University, Dhaka, Bangladesh, ${ }^{2}$ Kurmitola General Hospital,Dhaka, ${ }^{3}$ National Institute of \\ Kidney Diseases and Urology, Dhaka \\ Address of Correspondence: Dr Md Rasul Amin, Assistant professor, Department of Cardiology, Bangabandhu Sheikh Mujib \\ Medical University, Dhaka, Bangladesh Email:shepon28@yahoo.com
}

\begin{abstract}
:
Background: The stiffness of the large elastic arteries increase the morbidity and mortality. Objective: The purpose of the present study was to estimate the risk of aortic stiffness among end stage renal disease patients under maintenance haemodialysis. Methodology:This case-control study was carried out in the Department of Nephrology at National Institute of Kidney Diseases and Urology (NIKDU), Dhaka and National Institute of Cardiovascular Disease and Hospital (NICVD), Dhaka, Bangladesh from January 2013 to December 2014 for a period of two (02) years. Chronic kidney disease in stage 5 [CKD-5(D)] patients older than 18 years on maintenance haemodialysis (MHD) for more than 3 months were designated as case group and age and sex matched non CKD patients were considered as control group. Serum calcium, serum albumin, serum phosphate and iPTH were estimated by semi-automated biochemistry analyzer from the Department of Biochemistry of NIKDU, Dhaka and NICVD, Dhaka. Plain X-ray abdomen in lateral view was performed for all patients. Result: A total number of 100 patients were enrolled for this study of which 50 patients were in end stage renal disease (ESRD) group and the rest 50 patients were in non-CKD group. Mean $( \pm S D)$ aortic stiffness index was significantly higher $(P<0.001)$ among ESRD population (3.27 \pm 1.70$)$ compared to non CKD group of population (2.00 \pm 0.73$)$. Mean $( \pm S D)$ serum calcium (corrected) level was significantly high $(P<0.001)$ in ESRD patients $(9.79 \pm 0.87)$ compared to non $C K D$ group of population (9.13 \pm 0.70$)$. Mean $( \pm S D)$ serum phosphate level was significantly higher $(P<0.001)$ in ESRD patients (5.71 \pm 0.96$)$ compared to non CKD group of population (4.20 \pm 0.59$)$. However, mean $( \pm S D)$ iPTH level showed no significant difference between ESRD (25.33 \pm 51.98$)$ and non CKD group of population (38.53 \pm 19.52). Conclusion: In conclusionaortic stiffness is significantly higher among ESRD subjects.
\end{abstract}

Keywords: aortic stiffness; end stage renal disease; maintenance haemodialysis; risk estimation.

University Heart Journal 2018; 14(2): 67-70

Introduction:

Arterial stiffness is more in early chronic kidney disease (CKD) stages even in the absence of disease of intimal layer of arterial wall and independently of traditional CV risk factors. ${ }^{1}$ The contribution of traditional risk factors such as hypertension, aging, smoking, diabetes and abnormal lipid metabolism does not fully explain the high frequency of cardiovascular morbidity and mortality, in chronic kidney disease (CKD) population indicating that some other distinct pathology may be involved. ${ }^{2}$

Vascular calcification starts to develop in the early stage of CKD and is present over $50.0 \%$ of patients at the time of dialysis commencement. ${ }^{3}$ End-stage renal disease (ESRD) results in the development of cardiovascular alterations. Cardiac and vascular remodeling has haemodynamic consequences and humoral disorders which worsen with the disease duration. Such factors are central to understanding endothelial cell integrity and therefore, endothelial dysfunction, which refers to impairment of endothelium-dependent vasodilation. Calcifications increase the stiffness of the large elastic arteries like the aorta or the common carotid artery. 4 Decrease in the artery wall elasticity is associated with an increase in systolic arterial blood pressure, which results in left ventricular hypertrophy.Patients with ESRD have two-fivefold more coronary artery calcification than age- and sex-matched individuals with coronary artery disease alone. ${ }^{5}$ In addition, hyperphosphatemia, high calcium-phosphate product levels, deficiency of calcification inhibitors, and direct effects on vascular smooth muscle cells (VSMCs) are equally involved in the calcification process. ${ }^{6}$ 
Arterial stiffness can also be measured by ankle-brachial index (ABI). Each $1 \mathrm{~m} / \mathrm{s}$ increase in PWV was associated with a significant $15.0 \%$ higher risk of dying during the 24 months of follow-up. Higher phosphate level is strongly associated with the ankle-brachial index (ABI). A phosphate level $>4 \mathrm{mg} / \mathrm{dl}$ compared with $<3.0 \mathrm{mg} / \mathrm{dL}$ was associated with a significant fourfold increased risk for high ABI. ${ }^{7}$ This present study was undertaken to estimate the risk of aortic stiffness among end stage renal disease patients under maintenance haemodialysis.

\section{Methodology:}

This was a case-control study which was carried out in the Department of Nephrology at National Institute of Kidney Diseases and Urology (NIKDU), Dhaka and National Institute of Cardiovascular Disease and Hospital (NICVD), Dhaka, Bangladesh. This study was conducted from January 2013 to December 2014 for a period of two (02) years. Chronic kidney disease in stage 5 [CKD5(D)] patients older than 18 years on maintenance haemodialysis (MHD) for more than 3 months were designated as case group and age and sex matched non CKD patients were considered as control group. Purposive sampling method was followed as per inclusion and exclusion criteria. The patients of ESRD stage on maintenance hemodialysis at least two times per week (eight hours) for at least 3 months, patient's age more than 18 years, patients who gave informed consent were included in the case group. Age and sex matched control group with eGFR $>60 \mathrm{ml} / 1.73 \mathrm{~m}^{2} / \mathrm{min}$, urine routine microscopic examination normal (absence of RBC, proteinuria and cast) and USG shows no structural abnormalities, patient's age more than 18 years and patients who gave informed consent were included in the control group. Patient with congenital, valvular heart disease, pregnant women were excluded from this study. Serum calcium, serum albumin, serum phosphate and iPTH were estimated by semi-automated biochemistry analyzer from the Department of Biochemistry of NIKDU, Dhaka and NICVD, Dhaka. Furthermore, 2D and M-mode echocardiogram were used for the measurement of aortic stiffness. For exclusion of CKD in control group haemoglobin level, routine urine microscopic examination $(\mathrm{R} / \mathrm{M} / \mathrm{E})$, serum creatinine and ultrasonogram (USG) of kidney ureter and bladder (KUB) were also done. Results were analyzed with the use of the SPSS (Version 18.0, USA) statistical analysis software. The values were presented as mean and standard deviation or as numbers and percentages. The Student ttest, Chi-square test and logistic regression analysis was used. The value of $\mathrm{p}<0.05$ was considered as minimum level of significance.

\section{Results:}

This study was carried out with an aim to estimate the frequency of aortic stiffness among CKD-5(D) population and age and sex matched non-CKD patients.For this purpose, CKD-5(D) patients older than 18 years on MHD for more than 03 months (case) and control group was age- sex matched non CKD population.January 2013 to December 2014 were included in this study as per inclusion and exclusion criteria. The mean age with SD of case and control groups was $50.64 \pm 14.26$ years and $47.02 \pm 10.66$ years. The difference between the case and control group was not statistically significant $(\mathrm{p}>0.05)$ (Table 1$)$.

Table-I

Age Difference among the Study Subjects

\begin{tabular}{lccc}
\hline Variables & \multicolumn{2}{c}{ Group } & P value \\
& Case & Control & \\
\hline Age $($ Mean \pm SD) & $50.64 \pm 14.26$ & $47.02 \pm 10.66$ & $>0.05^{*}$ \\
\hline *Student t test was performed; **Chi-square Test was performed.
\end{tabular}

The mean aortic stiffness index with standard deviation was $3.27 \pm 1.70$ and $2.00 \pm 0.73$ in case and control group respectively. The difference between the case and control group was statistically significant $(p=0.00021)$. Therefore, aortic stiffness index was significantly higher among ESRD subjects (Table 2).

Table-II

Aortic stiffness index (Echocardiogram) among Case and control Group (Mean $\pm S D)$

\begin{tabular}{llc}
\hline Groups & Aortic Stiffness Index & P value \\
\hline Case Group & $3.27 \pm 1.70(0.948 .10)$ & 0.00021 \\
Control Group & $2.00 \pm 0.73(0.703 .90)$ & \\
\hline
\end{tabular}

Mean $( \pm \mathrm{SD})$ serum calcium (corrected) level was significantly high $(\mathrm{P}<0.001)$ in ESRD patients $(9.79 \pm 0.87)$ compared to non CKD group of population (9.13 \pm 0.70$)$. Mean $( \pm$ SD) serum phosphate level was significantly higher $(\mathrm{P}<0.001)$ in ESRD patients (5.71 \pm 0.96$)$ compared to non CKD group of population (4.20 \pm 0.59$)$. However, mean $( \pm$ SD) iPTH level showed no significant difference between ESRD $(25.33 \pm 51.98)$ and non CKD group of population (38.53 \pm 19.52$)$. Serum calcium, phosphate and iPTH were significantly higher among ESRD patients compared to control group (Student's t-test). 
Table-III

Comparison of Laboratory values between ESRD and Control group (Mean $\pm S D$ )

\begin{tabular}{lccc}
\hline Variables & \multicolumn{2}{c}{ Group } & P value \\
\cline { 2 - 3 } & Case & Control & \\
\hline Serum Calcium $(\mathrm{mg} / \mathrm{dL})$ & $9.79 \pm 0.87$ & $9.13 \pm 0.70$ & 0.0001 \\
Serum Phosphate $(\mathrm{mg} / \mathrm{dL})$ & $5.71 \pm 0.96$ & $4.20 \pm 0.59$ & 0.0001 \\
iPTH $(\mathrm{pg} / \mathrm{mL})$ & $25.33 \pm 51.98$ & $38.53 \pm 19.52$ & 0.096 \\
\hline
\end{tabular}

*Student $t$ test was performed to measure the level of statistical significance; iPTH= Parathyroid hormone

\section{Discussion:}

This case-control study was carried out with an aim to estimate the frequency of aortic stiffness among CKD5(D) population and to compare these complications between CKD-5(D) population and non- CKD population.In this current study it was observed that Mean $( \pm \mathrm{SD})$ age of the ESRD patients were $50.64 \pm 14.26$ (range 20.076 .0 ). Panuccio et $\mathrm{al}^{8}$ in Italy and Zapolskil et $\mathrm{al}^{9}$ in Poland showed the mean age of ESRD patients were $59 \pm 15$ years and $51.7 \pm 7.1$ years respectively, which are higher than the current study. This may be due to increased life expectancy including entry of more aged patients in dialysis and long duration of dialysis in their country.

In this study aortic stiffness index was significantly higher among ESRD population compared to non CKD patients $(3.27 \pm 1.70$ vs. $2.00 \pm 0.73, \mathrm{P}<0.001)$. Zapolski1 et $\mathrm{al}^{9}$ in a Polish study showed patients with ESRD had significantly higher values of the AS index: (5.34 vs. 3.24). In their study aortic stiffness index of ESRD population is higher than our ESRD patients (5.3 vs. 3.27 ), which may be due to greater duration of dialysis and greater surface area of their study population.

Mean $( \pm$ SD) serum calcium (corrected) level was significantly high $(\mathrm{P}<0.001)$ in ESRD population $(9.79 \pm 0.87$, range $8.211 .3 \mathrm{mg} / \mathrm{dl})$ compared to non CKD population $(9.13 \pm 0.70$, range $7.410 .8 \mathrm{mg} / \mathrm{dl})$. Mean $( \pm \mathrm{SD})$ serum phosphate level was significantly high $(\mathrm{P}<0.001)$ in ESRD population $(5.71 \pm 0.96$, range 4.2 $9.7 \mathrm{mg} / \mathrm{dl})$ compared to non CKD population ( $4.20 \pm 0.59$, range $2.85 .8 \mathrm{mg} / \mathrm{dl}$ ). However, iPTH level showed no significant difference between ESRD and non CKD (25.33 \pm 51.98 vs. $38.53 \pm 19.52 \mathrm{pg} / \mathrm{ml}, \mathrm{p}>0.05)$ population. Similar study was done by Shaarawy et al ${ }^{10}$ in Ain Shams University, where they compared 60 patients on regular HD with 25 non CKD patients. Tomiyama et al ${ }^{11}$ showed in their study low serum PTH value has been associated with poor outcomes in CKD. Chertow et al. (2004) showed lower PTH levels are associated with more extensive calcification in calcium treated subjects. Satterwhite et al ${ }^{12}$ showed with PTH supplementation (teriparatide) via a direct effect on osteopontin could inhibit vascular calcification and aortic osteogenic differentiation. ${ }^{\wedge}$ atirolu et $\mathrm{al}^{13}$ from Turkey shows in their study the mean aortic stiffness in Group I (with coronary artery disease) was significantly increased compared to Group II with normal coronary artery (8.9 $\pm 5.1 \mathrm{~mm}$ and $6.1 \pm 4.6 \mathrm{~mm}$, respectively; $\mathrm{P}=0.001)$. In the Polish study by Zapolski et al $^{9}$ showed among 60 patients with ESRD on dialysis with a mean age of 51.7 years, those with the stiffer aorta, atherosclerotic plaques including calcification and the aortic valve damage were more frequently detected.

A study by the United States Renal Disease Data System (USRDS) indicates longer dialysis duration is associated with higher mortality. This data also leads us to believe that end-stage renal disease is a primary promoter of cardiac disease and increased risk for sudden cardiac death. Parfitt et al ${ }^{14}$ showed in their study, the increment in serum calcium during dialysis was partly due to the high calcium level of the dialysate $(6.87 \pm 0.58 \mathrm{mg} / 100$ $\mathrm{ml}$ ), but there was considerable variation between patients which was only partly explained by individual differences and partially by the use of phosphate binders for the correction of hyperphosphatemia in uremia. Although some patients showed a fall in predialysis serum phosphate levels in the first few months, high levels eventually developed in all.

\section{Conclusion:}

In conclusion aortic stiffness is statistically significantly associated with end stage renal disease patients who are under maintenance haemodialysis. This is positively correlated with the serum calcium level. Furthermore serum calcium and phosphate are also statistically significantly related with end stage renal disease patients. Further large scale study should be carried out. 


\section{References:}

1. Chin MP, Wrolstad D, Bakris GL, Chertow GM, de Zeeuw D, Goldsberry A, Linde PG, McCullough PA, McMurray JJ, Wittes J, Meyer CJ. Risk factors for heart failure in patients with type 2 diabetes mellitus and stage 4 chronic kidney disease treated with bardoxolone methyl. Journal of cardiac failure. 2014 Dec 1;20(12):953-8

2. London GM, Marchais SJ, Guérin AP, Boutouyrie P, Métivier F, de Vernejoul MC. Association of bone activity, calcium load, aortic stiffness, and calcifications in ESRD. Journal of the American Society of Nephrology. 2008 Sep 1;19(9):1827-35

3. Ix JH, De Boer IH, Peralta CA, Adeney KL, Duprez DA, Jenny NS, Siscovick DS, Kestenbaum BR. Serum phosphorus concentrations and arterial stiffness among individuals with normal kidney function to moderate kidney disease in MESA. Clinical Journal of the American Society of Nephrology. 2009 Mar 1;4(3):609-15

4. Guérin AP, London GM, Marchais SJ, Metivier F. Arterial stiffening and vascular calcifications in end stage renal disease. Nephrology Dialysis Transplantation. 2000 Jul 1;15(7):1014-21

5. Wright J, Hutchison A. Cardiovascular disease in patients with chronic kidney disease. Vascular health and risk management. 2009;5:713

6. Blacher J, Guerin AP, Pannier B, Marchais SJ, Safar ME, London GM. Impact of aortic stiffness on survival in end-stage renal disease. Circulation. 1999 May 11;99(18):2434-9

7. Blacher J, Safar ME, Pannier B, Guerin AP, Marchais SJ, London GM. Prognostic significance of arterial stiffness measurements in end-stage renal disease patients. Current opinion in nephrology and hypertension. 2002 Nov 1;11(6):629-34

8. Panuccio V, Tripepi R, Tripepi G, Mallamaci F, Benedetto FA, Cataliotti A, Bellanuova I, Giacone G, Malatino LS, Zoccali C. Heart valve calcifications, survival, and cardiovascular risk in hemodialysis patients. American Journal of Kidney Diseases. 2004;43(3):479-84

9. Zapolski T, Wysokinski A, Janicka L, Grzebalska A, Ksiazek A. Aortic stiffness and valvular calcifications in patients with endstage renal disease. PolskieArchiwumMedycynyWewnetrznej. 2008 Mar;118(3):111.

10. Shaarawy AB, Hosny M, Raafat M, Gendy N. Study of Cardiac Valvular Calcification in ESRD Patients on Regular Hemodialysis (A Single Center Study). Life Science Journal. 2012;9(3)

11. Tomiyama C, Carvalho AB, Higa A, Jorgetti V, Draibe SA, Canziani ME. Coronary calcification is associated with lower bone formation rate in CKD patients not yet in dialysis treatment. Journal of Bone and Mineral Research. 2010 Mar 1;25(3):499-504

12. Satterwhite J, Heathman M, Miller PD, Marín F, Glass EV, Dobnig H. Pharmacokinetics of teriparatide (rhPTH [1-34]) and calcium pharmacodynamics in postmenopausal women with osteoporosis. Calcified tissue international. 2010 Dec 1;87(6):485-92

13. ^atirolu Ö, Bostan M, Bayar N, Çiçek Y, Cetin M, Bozkurt E. Relation between aortic stiffness and extension of coronary artery disease. Turkish Journal of Medical Sciences. 2012 May 25;42(3):417-24

14. Parfitt AM. Soft-tissue calcification in uremia. Archives of internal medicine. 1969 Nov 1;124(5):544-56. 